\title{
COMMUNAL SPACES AND COMMUNITY LIFE IN GATED DEVELOPMENTS
}

\author{
Faisal Abdul Maksoud*, Prof. Seamus Filor** and Ghada Yassein* \\ *Department of Architecture, Menoufeya University, Egypt \\ ** Department of Landscape Architecture, University of Edinburgh, Scotland, UK
}

\begin{abstract}
Attractive communal open spaces with recreational facilities in gated residential developments are the market solution to provide collective club goods fulfilling the diverse preferences of prospective homebuyers. The issue is that communal open spaces are supposed to promote community life; it has been argued that residents moving into cohousing or developments associated with shared open spaces are likely those who are most predisposed to the idea of community life and seek to make it available. This paper develops a framework for measuring benefits of communal spaces to surrounding residents, specifically psychological effects: sense of identity, sense of community, and sense of well being. A questionnaire survey was constructed based on the review of literature. In general, the study dealt with residents of 16 gated developments from various areas in Egypt. The questionnaire results were compiled and analysed using SPSS statistical software. The first step was exploratory analysis to describe the respondents and their preferences. The second step was testing psychological values of communal spaces.
\end{abstract}

It is concluded that communal spaces could enhance the quality of life for the residents of gated developments by establishing a sense of place along with influencing their physical and psychological health and well-being. Whilst the space is not understood as a collective space; an individualized lifestyle emerges contributing to the more lenient attitude towards social activities among neighbours. The research findings constitute a comprehensive approach considering household preferences and perceptions to evaluate urban landscapes objectively.

Keywords: Gated residential developments (GRDs) - Communal/Shared open space (SOS) Sense of community - Sense of identity - Sense of wellbeing

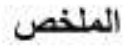

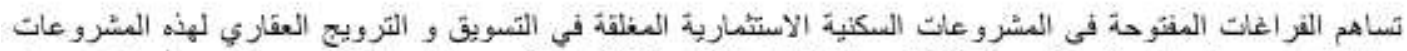

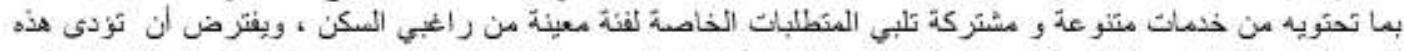

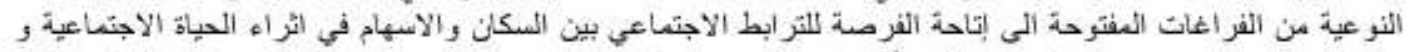

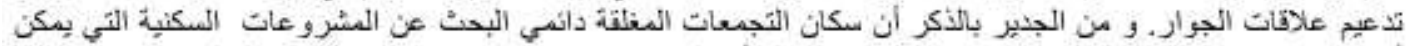

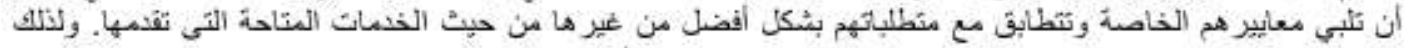

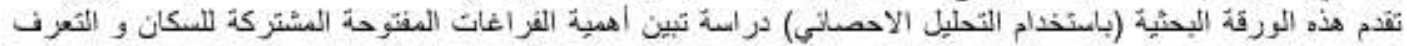

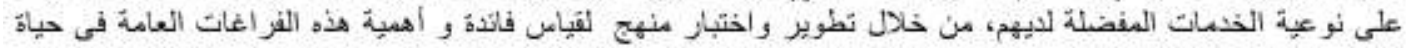

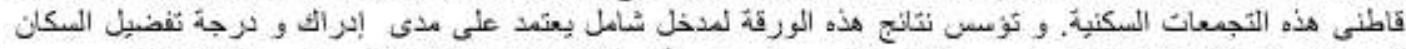

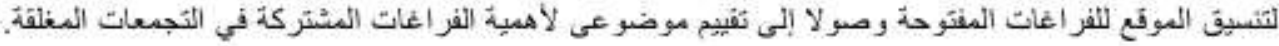




\section{INTRODUCTION}

Human perception appears to be critical for understanding the interactions between humans and landscapes. Numerous studies have dealt with the relationship between landscape elements and human perception. For instance, (Tress \& Tress, 2001) indicated that through their actions, people affect the landscape, and the landscape affects people by its appearance. Many studies also support the natural environments' benefits for urban residents. A related literature classified outdoor spaces into four broad categories (Marcus, 2003): (a) private spaces owned by individuals and accessible only to them and their guests such as yards of private homes; (b) public spaces including neighborhood parks and streets that are publicly owned and accessible to all; (c) a third intermediate category consists of spaces such as corporate plaza or a university campus; and (d) communal spaces owned by a group and usually accessible only to that group such as community gardens and the common landscaped areas of condominium developments and clustered housing.

Some studies suggest that this fourth category are spaces for community interaction, appropriate to the densities and lifestyles specially in suburban neighborhoods (Bill, 2001; Sullivan, 2006). Additionally, (Talen, 2003:78) argues that groups of residents moving into cohousing or developments associated with shared open space are likely those who are "most predisposed to the idea of community life" and consequently "most like to actively seek it out".

The subject of this study is the communal spaces ${ }^{1}$ in gated developments (commonly known as compounds) located on the fringe of the Greater Cairo Region in new desert towns and main regional roads such as: (Cairo /Alexandria and Cairo/Ismailia desert roads). It aims to explore residents' preferences for the physical aspects of communal spaces and to assess their psychological benefits, particularly assessing the community life which is used as a marketing tool ${ }^{2}$.

Before proceeding further, communal space can be defined - based on several related researches - as a type of shared space that facilitates interaction between residents of a gated development. This common shared landscape area with significant amounts of vegetation is frequently jointly owned and maintained by the residents in a type of management structure.

\section{THEORETICAL BACKGROUND}

Following the purpose of this study, two aspects of open spaces are discussed below, namely psychological and physical aspects.

\footnotetext{
${ }^{1}$ Communal space and shared open space (SOS) will be used interchangeably for the same concept.

${ }^{2}$ This paper is a revised version of hypothesis 2 (i.e. SOS has a positive impact on gated developments dwellers) of the doctoral dissertation titled:"The Role of Urban Landscape Architecture in the Economics of the Investment Areas". The defense should take place within three months.
} 


\subsection{Psychological Aspects}

A. Supporting a sense of identity: The sense of place and identity is a feeling of being somewhere special and preferably unique, which the designers and developers need to strive in site layout planning for residential area. A feeling of being in a particular 'place', contribute so significantly to develop a sense of belonging and pride which is vital to support the sense of community.

B. Fostering a sense of community: Several studies support that the lack of semiprivate shared spaces in residential projects is related with a decrease in positive social relations and sense of community. Additionally, the existence of shared spaces, well-landscaped grounds, places for taking walks and nearby nature contribute to an increased ability to exchange emotional relations with people.

C. Promoting a sense of well-being: After the Green Revolution in 1960, several researches aimed to study the person-environment relationship, specifically studying the impact of the environment on psychological well-being. These researches have proven that nature provides many benefits to human well-being. It helps reducing stress and restore directed attention and mental fatigue caused by noise and crowding. Studies have also found that dwellers do not necessarily want open spaces for specific active recreation; their first reason for using open space is the contact with nature, and just knowing that a green space is available nearby comforts them even they do not use it (Clement, 2004; Kaplan, 1983).

\subsection{Physical Aspects}

\section{A. Characteristics of communal space:}

The category of outdoor space that has been defined here as 'communal space' can be a highly significant component of the residential environment if it fulfills the following characteristics ${ }^{3}$ :

- Location: Communal space should be bounded by the dwellings it serves; it should be no further than 400 metres, or five minutes walk from any dwelling (Thompson, 2008).

- Boundaries: There is a clear separation and easy access between communal space and private space (dwelling unit, patio, and yard).

- Dimensions: Communal space should always be of a reasonable size and shape. The height-to-width ratio of buildings to outdoor space should be also considered to form a human-scaled setting related to activities.

\footnotetext{
${ }^{3}$ An important characteristic of communal space is the inclusion of "Safer by Design" elements known as "Crime Prevention". The research will not attempt to address this aspect as it is concerned with the study of open space in gated developments where the four primary principles of Safer by Design (surveillance, access control, territorial reinforcement, management and maintenance) are presented.
} 
- Connection: It means a possible view of communal space from dwelling units, which provide an opportunity for parents to observe their children from indoors.

- Setting: Need to focus on circulation patterns, paths for wheeled vehicles, furnishings, lighting and particularly children's play equipment (Marcus, 2001).

- Planting: Plant material is not an 'added extra' for decorating, but something that can alter the whole social as well as aesthetic value of the estate (Bee, 2000b). Previous researches showed that the frequently cited reasons for using outdoor space were contact with nature and relaxing (Marcus \& Francis, 1997). Trees also were found to be the most effective environmental predictor for being "at peace" and feeling "less distracted" (Kaplan, 2001). Therefore, making available plants with various colours, textures, odors and shapes, as well as water features (e.g. fountains, pools and waterfalls) are essential to fulfill relaxing feelings.

- Management: The management controls should seek to provide a suitable level of amenity and a range of outdoor activities to encourage high usage patterns.

- Maintenance: Communal space should also be well maintained to ensure that landscaped areas do not become overgrown or unsafe, and the play equipment does not become broken down.

- Sustainability: Open space must remain viable in the long term. Design and management should respond to development aspirations, economic considerations, as well as environmental values and conditions.

\section{B. Users' needs within communal open space}

User needs are defined as amenities and experiences that people look for to enjoy open spaces (Francis, 2003). In this sense, a consideration of what the users might need from a built environment must often be well thought-out. "When it comes to designing and building a space, the best an architect can do is to match the needs and desires of potential users with a space that facilitates them." (Sullivan, 2006:6).

The process to link information about users' needs to open space is preparing activity list of the different recreational activities needed, then establishing a setting to support these activities and allow them to occur in a pleasant and enjoyable way (Bee, 2000a).

The terms 'active' and 'passive' are used to describe the types of activities undertaken in open space areas. Active use signifies sporting and functions that often take place in areas such as sports pitches, playing fields, tennis courts, and other spaces for outdoor sports. Passive use means making use of the space without a specifically organised sporting activity such as relaxing, enjoying the view, and all other recreational purposes (Thompson, 2008). Table (1) sets out examples of amenity threshold required for residential developments en route for establishing a generic standard for open space facilities to improve opportunities for a wide range of activities suitable for all residents. 
Table (1) The Amenity Threshold Required for Residential Developments.

\begin{tabular}{|c|c|c|c|c|}
\hline $\begin{array}{c}\text { Number } \\
\text { of } \\
\text { Dwellings }\end{array}$ & $<25$ & $25-50$ & $50-75$ & $75-100+$ \\
\hline $\begin{array}{l}\text { Amenity } \\
\text { required }\end{array}$ & $\begin{array}{l}\text { - Landscaped } \\
\text { recreational } \\
\text { area (setting } \\
\text { out) } \\
\text { - Active amenity } \\
\text { open space } \\
\text { (Ball Games) } \\
\text { - Informal play } \\
\text { areas. }\end{array}$ & $\begin{array}{l}\text { Providing similar } \\
\text { activities to those } \\
\text { mentioned on the } \\
\text { left, as well as: } \\
\text { - Areas for } \\
\text { younger } \\
\text { children (play } \\
\text { ground) } \\
\text { (min. } 400 \mathrm{~m}^{2} \text { ) } \\
\text { - Areas for older } \\
\text { children } \\
\text { (shelter space } \\
\text { facilities) } \\
\text { (min. } 1000 \mathrm{~m}^{2} \text { ). }\end{array}$ & $\begin{array}{l}\text { Providing similar } \\
\text { activities to those } \\
\text { mentioned on the } \\
\text { left, plus either of: } \\
\text { - Grass sports } \\
\text { pitch/ playing } \\
\text { fields } \\
\text { - Multi Use } \\
\text { Games Area } \\
\text { (tennis/basket } \\
\text { ball) } \\
\text { Community } \\
\text { facilities } \\
\text { (meeting } \\
\text { rooms, } \\
\text { communal } \\
\text { equipment } \\
\text { storage, etc). }\end{array}$ & $\begin{array}{l}\text { Providing similar } \\
\text { activities to those } \\
\text { mentioned on the } \\
\text { left, plus either of: } \\
\text { - All weather } \\
\text { playing pitches } \\
\text { - Bowling Green } \\
\text { - Skateboard/ } \\
\text { BMX area } \\
\text { - Tot Lot. }\end{array}$ \\
\hline
\end{tabular}

Source: Laois County Council. Open Space Considerations for Residential Developments.

To end with, a residential development needs an integrated open space that meets the needs of residents, facilitates social interactions, encourages a healthy lifestyle and provides a variety of recreational opportunities and activities matched to the setting and environment of the area. At the same time it is important to recognise that no environment will be suited to all types of recreation plus most spaces do not serve everybody and it may be unrealistic to expect them to do so (Marcus \& Francis, 1997).

\section{METHODOLOGY AND RESEARCH SCOPE}

The research methodology constitutes a comprehensive approach considering household preferences and perceptions. Benefits of communal space were represented by psychological aspects ${ }^{4}$. They consist of optional activities and social activities: Optional activities include active use (e.g. doing some sports, walking); and passive use (e.g. relaxation and enjoying the view). Social activities depend on the presence of others in open spaces (e.g. meeting neighbours, accompanying children, recreation time with family) (Gehl, 2003). (Figure 1) points up physical and psychological aspects: physical aspects were designated as independent variables including boundaries, area, and accessibility; psychological aspects were dependents variables consisting of sense of community, sense of well being and sense of identity.

\footnotetext{
${ }^{4}$ A previous study presented a psychological conceptualization of residential choice where activities leading to the achievement of life values were identified as objectives (Xiaoyu, Jian, Fei, \& Hokao, 2007:300.
} 
Figure (1) Variables for Testing Benefits of Communal Spaces

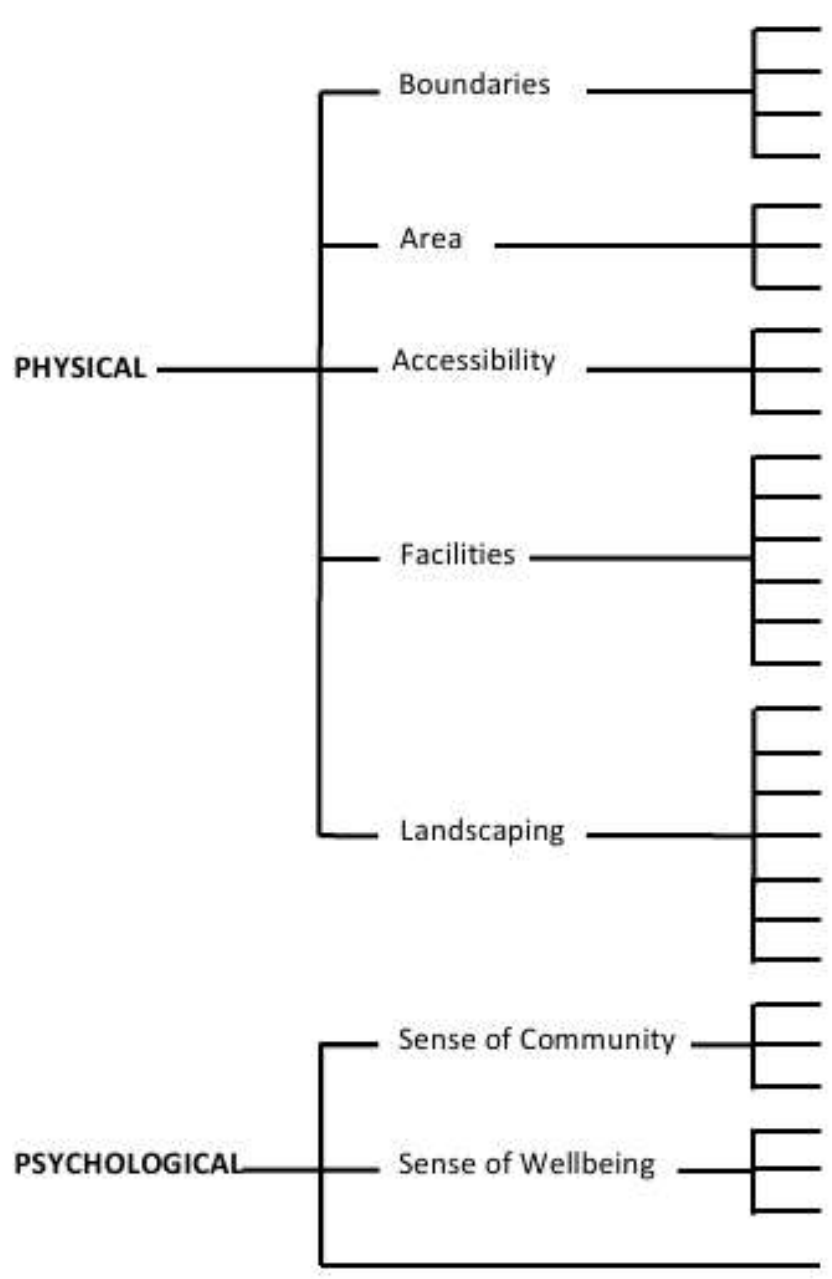

Project with gate

Fenced Project without gate

Project without gate, but with gated SC

Bigger private garden instead of SOS

Small Area

Medium Area

Large Area

Less than 5 minutes

From 5 - 10 minutes

More than 10 minutes

Children playground

Pergolas/shaded places/arbors

Sitting area/benches

Snack bar

Swimming pool

Outdoor exercise facilities

Type of landscape

Trees

Shrubs

Flowers

Lawn / turf

Hardscape

Water features

Meeting my neighbours

Accompany children

Recreation time with family

Doing some sports

Walking

Relaxation \& Enjoying the view

Sense of Identity

\subsection{Methods and data}

A self-administered questionnaire ${ }^{5}$ was developed for conducting the Preference Survey. It was designed to assess residents' preferences for the specific physical

\footnotetext{
${ }^{5}$ The self-administered questionnaire is a questionnaire that a respondent completes on his/her own, either on paper or via computer. The Preference Survey was conducted in December 2008, the target study subjects were current residents who moved to relatively new gated residential developments. The collection of data proved to be extremely difficult. The investigator first, tried to contact the facility managers of some developments and explained the purpose and procedure of the study. After several conversations, quite a few agreed to support the investigation by assigning their security staff to distribute and collect the questionnaires, but the inhabitants were cagey about answering and the questionnaires were rarely returned. Therefore, a snowball-type networking system was used with the aim of getting a better sample survey. The study dealt with residents of 16 (GRDs): Al Rehab City Dream Land -Solimaneya Gardens- Elmohandessen Garden- Mena Gardens- Katameya Heights- Al Ahram Gardens- Beverly Hills- Moon Land-Zayed 2000- Al Worood-Royal Hills- Hay Al Ashgar- Palm Hills- Golf El Solaimaneyah- El Shorouk 2000. The total number of valid responses was 76, however the homogeneity established in gated GRDs compensates the small sample size.
} 
characteristics and psychological outcomes of communal spaces in gated residential developments. The questionnaire was constructed based on the review of literature in addition to questions adapted from 'Neighbourhood Question Bank' . Questionnaire design and forms mostly followed Total Design Method (TDM) guidelines for questionnaire preparation.

The survey was assessed for reliability using a test-retest method to verify that responses were consistent over time (two weeks). The data collected from questionnaires were people's self-reported preferences and opinions regarding communal spaces in gated developments. Therefore, the use of parametric methods were been justified, also the reliability and normality of the survey were been tested. Both descriptive and inferential statistics were been used to analyse the same set of data by utilization of SPSS Statistics (17.0). Site visits were used also to ground-truth data analysis. Two paradigms provide different type of results contributing to the holistic understanding of the preferences and perceptions of residents for their communal spaces. The exploratory paradigm provides understanding of the preference patterns. The predictive paradigm predicts benefits by predictor variables.

\subsection{Results}

The study dealt with residents of 16 (GRDs) from various areas. The total number of responses to the resident survey was 76 . Among them, $36.8 \%$ were male and $63.2 \%$ were female. The age of the respondents was categorized into three groups; $18.4 \%$ were less than 21 years old, $57.9 \%$ were in the age group of 21 to 35 years old, and $23.7 \%$ were in the age group of 36 to 60 years old. Among the 76 respondents, $33.3 \%$ were single and $66.7 \%$ were married. The family size of the respondents was also categorized into three groups; $16.2 \%$ were $1-2$ members, $59.5 \%$ were $3-4$ members, and $24.3 \%$ were more than four family members. A total of 43 dwelling units out of 76 were individual houses with a percentage of $56.6 \%$, and 33 were apartment flats with a percentage of $43.4 \%$. Since these gated projects are a new phenomenon (mostly developed after the year 2000), of those that responded, only $22.7 \%$ respondents had lived there less than one year; $44 \%$ respondents had lived there from one to three years; and $33.3 \%$ respondents had lived there longer than three years.

The most commonly reported advantages of living in (GRDs) were 'quiet space to live in' and 'privacy', while on the contrary 'sense of community' and 'price \& schedule of payment' were reported as the fewer advantages. Respondents were very proud of their residential environment (sense of identity). They very highly preferred 'project with gate'; 'large sized shared space'; 'children play ground'; 'pergolas/shaded places/arbors'; 'sitting area/benches'; 'walking'; 'relaxation \& enjoying the view'. As for 'meeting my neighbours', it was not very much preferred (the seventeenth preference from a total of twenty-three) (Figure 2 and Table 2).

\footnotetext{
${ }^{6}$ The ESRC Centre for Neighbourhood Research (CNR), available at http://www.neighbourhoodcentre.org.uk/bank/bank.html
} 
Figure (2) Weights Placed on Preference Variables

\begin{tabular}{|c|c|c|c|c|}
\hline Variable & Description & $\begin{array}{l}\text { Weight } \\
\text { value* }\end{array}$ & & \\
\hline$x 1 \_1$ & Project with gate & 93.9 & & \\
\hline$x 1 \_5$ & Sense of identity & 92 & & \\
\hline x3_3 & Sitting area & 89.1 & $\times 1.1100^{\times 2.1}$ & \\
\hline$x 4 \_5$ & walking & 89 & & \\
\hline x3_2 & Pergolas \& shaded area & 88.5 & & \\
\hline$x 4 \_6$ & $\begin{array}{l}\text { Relaxing \& enjoying the } \\
\text { view }\end{array}$ & 86.4 & & $\times 2.6$ \\
\hline$x 2 \_3$ & large area & 85.9 & & \\
\hline x3_1 & Children play ground & 85 & $\times 4.6$ & $\times 4.1$ \\
\hline x4_4 & Doing some sports & 83.8 & & \\
\hline$x 1 \_4$ & $\begin{array}{l}\text { Bigger private garden } \\
\text { instead of shared open } \\
\text { space }\end{array}$ & 83.2 & $x^{2}$ & $\times 3.6$ \\
\hline$x 3 \_5$ & Swimming pool & 81.1 & 4 & \\
\hline$x 3 \_4$ & Snack bar & 81 & 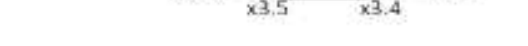 & \\
\hline$x 4 \_3$ & Recreation with family & 80 & & \\
\hline$x 2 \_4$ & $\begin{array}{l}\text { At a distance less than } 5 \\
\text { minutes }\end{array}$ & 79.2 & & Weight \\
\hline$x 4 \_2$ & Accompany children & 78.7 & Variable Description & value* \\
\hline$x 3 \_6$ & Exercise facilities & 71 & Medium area & 47.7 \\
\hline$x 4 \_1$ & Meeting neighbours & 66.7 & Project without gate, & 44 \\
\hline$x 2 \_5$ & $\begin{array}{l}\text { At a distance } 5-10 \\
\text { minutes }\end{array}$ & 54.7 & $\begin{array}{l}\text { but gated shared open } \\
\text { space }\end{array}$ & \\
\hline$x 2 \_6$ & At a distance more than & 51 & Project without gate & 38.4 \\
\hline & 10 minutes & & Small area & 35.9 \\
\hline
\end{tabular}

*The weights placed on preference items are assumed to reflect the importance of these values as determined by respondents' scores.

The researchers used inferential statistics to assess the psychological values of communal spaces. These values are sense of identity; sense of community; and sense of wellbeing. The variables used were as follows:

\section{- Dependent variables (D)}

Seven continuous variables representing activities leading to the achievement of psychological values as follows:

\section{Sense of identity} (x1_5)

\section{Sense of community}

$\left(x 4 \_1\right),\left(x 4 \_2\right),\left(x 4 \_3\right)$
Sense of well being

$\left(x 4 \_4\right),\left(x 4 \_5\right),\left(x 4 \_6\right)$

\section{- Independent variables (ID)}

Combination of various variable types representing 4 proxies of open space visits and 19 proxies of physical features as follows:

\section{Communal space visits}

Outside open space visits (E_3)

Frequency of visits to outside open spaces (E_4)

Frequency of visits to communal open space (E_5)

Preferred season for visiting communal open space

(E_6)
Physical features of communal space

Area \& Accessibility

( $\left.x 2 \_1, x 2 \_2, x 2 \_3, x 2 \_4, x 2 \_5, x 2 \_6\right)$

Facilities

(x3_1, x3_2, x3_3, x3_4, x3_5, x3_6)

Landscaping

(x5_1, x5_2, x5_3, x5_4, x5_5, x5_6, x5_7) 
Table (2) Questionnaire Responses to Preferences Variables

\begin{tabular}{|c|c|c|c|c|c|c|c|c|}
\hline \multirow[b]{2}{*}{ Variable* } & \multirow[t]{2}{*}{ Mean } & \multicolumn{5}{|c|}{ Percent** } & \multicolumn{2}{|c|}{ Weighted Average $(w)^{* * *}$} \\
\hline & & 1 & 2 & 3 & 4 & 5 & Percent & Description \\
\hline x1_1 & 4.69 & 0 & 0 & 3.9 & 22.4 & 72.4 & 93.9 & Very high \\
\hline x1_2 & 1.93 & 35.5 & 46.1 & 11.8 & 5.3 & 0 & 38.4 & Low \\
\hline x1_3 & 2.16 & 27.6 & 38.2 & 23.7 & 3.9 & 5.3 & 44 & Moderate \\
\hline x1_4 & 4.18 & 1.3 & 2.6 & 21.1 & 27.6 & 46.1 & 83.2 & Very high \\
\hline x1_5 & 4.59 & 1.3 & 1.3 & 5.3 & 19.7 & 71.1 & 92 & Very high \\
\hline x2_1 & 1.81 & 43.4 & 35.5 & 13.2 & 5.3 & 0 & 35.9 & Low \\
\hline$x 2 \_2$ & 2.41 & 25 & 28.9 & 28.9 & 13.2 & 2.6 & 47.7 & Moderate \\
\hline$x 2 \_3$ & 4.29 & 2.6 & 7.9 & 7.9 & 18.4 & 60.5 & 85.9 & Very high \\
\hline x2_4 & 3.95 & 2.6 & 7.9 & 25 & 18.4 & 44.7 & 79.2 & High \\
\hline x2_5 & 2.72 & 15.8 & 23.7 & 30.3 & 19.7 & 5.3 & 54.7 & Moderate \\
\hline$x 2 \_6$ & 2.56 & 23.7 & 30.3 & 19.7 & 10.5 & 11.8 & 51 & Moderate \\
\hline x3_1 & 4.24 & 2.6 & 1.3 & 18.4 & 33.4 & 53.9 & 85 & Very high \\
\hline x3_2 & 4.43 & 0 & 1.3 & 5.3 & 42.1 & 50 & 88.5 & Very high \\
\hline x3_3 & 4.45 & 1.3 & 0 & 5.3 & 38.2 & 53.9 & 89.1 & Very high \\
\hline x3_4 & 4.03 & 3.9 & 5.3 & 19.7 & 23.7 & 46.1 & 81 & Very high \\
\hline x3_5 & 4.07 & 2.9 & 7.9 & 17 & 25 & 46.1 & 81.1 & Very high \\
\hline x3_6 & 3.55 & 3.9 & 15.8 & 32.9 & 15.8 & 30.3 & 71 & High \\
\hline$x 4 \_1$ & 3.34 & 1.3 & 15.8 & 42.1 & 27.6 & 11.8 & 66.7 & High \\
\hline$x 4$ _2 & 3.92 & 2.6 & 5.3 & 21.1 & 36.8 & 32.9 & 78.7 & High \\
\hline$x 4$ _3 & 4.01 & 1.3 & 7.8 & 14.5 & 40.8 & 34.2 & 80 & High \\
\hline x4_4 & 4.21 & 2.6 & 0 & 18.4 & 31.6 & 44.7 & 83.8 & Very high \\
\hline$x 4 \_5$ & 4.43 & 0 & 0 & 9.2 & 36.8 & 52.6 & 89 & Very high \\
\hline x4_6 & 4.34 & 0 & 0 & 22.4 & 22.4 & 53.9 & 86.4 & Very high \\
\hline
\end{tabular}

*Variables description (see figure 2 ).

** Completely disagree $=1$, Tend to disagree $=2$, Indifferent $=3$, Tend to agree $=4$, and Completely agree $=5$.

***The difference in each interval $=19$ corresponding to a verbal description: $1-20 \%$ Very low; $21-40 \%$ Low; $41-60 \%$ Moderate; $61-80 \%$ High; $81-100 \%$ Very high.

Stepwise multiple regression was performed to find the most parsimonious set of predictors that are most effective in predicting the dependent variable. In stepwise regression, the relationship will always be significant if any variables are included because the variables can only be included if they contributed to a statistically significant relationship ${ }^{7}$. The results of regression analyses are grouped in (Table 3 ), the multiple regression models and the normal distribution of residuals are presented in (Figure 3).

\footnotetext{
${ }^{7}$ The SPSS computer program is allowed to choose a small set of the best predictors from the set of all potential predictors. Since variables will not be added to the regression equation unless they make a statistically significant addition to the analysis, all of the independent variables selected for inclusion will have a statistically significant relationship to the dependent variable.
} 
Table (3) Summary of Regression Analyses

\begin{tabular}{|c|c|c|c|c|c|c|c|c|}
\hline \multicolumn{2}{|c|}{$\begin{array}{l}\text { Predicted values } \\
\text { (Dependent variables) }\end{array}$} & \multirow[t]{2}{*}{$R^{2}$} & \multicolumn{2}{|c|}{$\begin{array}{l}\text { Variables with significant } \\
\text { contribution } \\
\text { (predictors) }\end{array}$} & \multirow[t]{2}{*}{ B } & \multirow[t]{2}{*}{ SE B } & \multirow[t]{2}{*}{6} & \multirow[t]{2}{*}{ Significance } \\
\hline Label & Description & & Label & Description & & & & \\
\hline \multicolumn{9}{|c|}{ Sense of identity } \\
\hline \multirow[t]{2}{*}{$x 1 \_5$} & $\begin{array}{l}\text { I am proud that } \\
\text { this project is } \\
\text { my address }\end{array}$ & .258 & E_3 & $\begin{array}{l}\text { Do you visit any } \\
\text { open space } \\
\text { outside your } \\
\text { project? }\end{array}$ & $.650_{\{a\}}$ & .174 & .395 & $.000^{* *}$ \\
\hline & & & E_5 & $\begin{array}{l}\text { How often do you } \\
\text { use communal } \\
\text { space in your } \\
\text { project? }\end{array}$ & $-.280_{(b)}$ & .091 & -.324 & \\
\hline \multicolumn{9}{|c|}{ Sense of community } \\
\hline$x^{4} \_1$ & $\begin{array}{l}\text { Meeting my } \\
\text { neighbours }\end{array}$ & - & - & - & - & - & - & - \\
\hline \multirow[t]{2}{*}{$x^{4} \_2$} & $\begin{array}{l}\text { Accompanying } \\
\text { children }\end{array}$ & .287 & x3_1 & $\begin{array}{l}\text { Children play } \\
\text { ground }\end{array}$ & .439 & .115 & .399 & $.000^{* *}$ \\
\hline & & & $x 2 \_4$ & $\begin{array}{l}\text { A communal } \\
\text { space reachable } \\
\text { at walking } \\
\text { distance less than } \\
5 \text { minutes }\end{array}$ & .298 & .093 & .335 & \\
\hline \multirow[t]{3}{*}{$x 4 \_3$} & $\begin{array}{l}\text { Recreation time } \\
\text { with family }\end{array}$ & .225 & x3_1 & $\begin{array}{l}\text { Children play } \\
\text { ground }\end{array}$ & .441 & .117 & .426 & $.000^{* *}$ \\
\hline & & & E_6 & $\begin{array}{l}\text { Which season do } \\
\text { you most often } \\
\text { use your } \\
\text { communal space } \\
\text { area? }\end{array}$ & $.190_{|c|}$ & .073 & .281 & \\
\hline & & & $x 3 \_4$ & Snack bar & -.208 & .100 & -.234 & \\
\hline \multicolumn{9}{|c|}{ Sense of wellbeing } \\
\hline \multirow[t]{3}{*}{$x 4 \_4$} & $\begin{array}{l}\text { Doing some } \\
\text { sports }\end{array}$ & .224 & E_5 & $\begin{array}{l}\text { How often do you } \\
\text { use communal } \\
\text { space in your } \\
\text { project? }\end{array}$ & $-.346_{(b)}$ & .113 & -.334 & $.000^{* *}$ \\
\hline & & & $\times 3 \_5$ & Swimming pool & .221 & .090 & .268 & \\
\hline & & & $\times 5 \_7$ & Water features & $-.462_{\text {(d) }}$ & .202 & -.249 & \\
\hline$x 4 \_5$ & Walking & .088 & $x 2 \_6$ & $\begin{array}{l}\text { A communal } \\
\text { space reachable } \\
\text { at walking } \\
\text { distance more } \\
\text { than } 10 \text { minutes }\end{array}$ & .157 & .057 & .318 & $.008^{*}$ \\
\hline \multirow[t]{2}{*}{$x 4 \_6$} & $\begin{array}{l}\text { Relaxation } \& \\
\text { Enjoying the } \\
\text { view }\end{array}$ & .113 & $E_{-} 3$ & $\begin{array}{l}\text { Do you visit any } \\
\text { open space } \\
\text { outside your } \\
\text { project? }\end{array}$ & $-.502_{(a)}$ & .197 & -.294 & $.007^{*}$ \\
\hline & & & $x 5 \_4$ & Flowers & $-.394_{|0|}$ & .186 & -.243 & \\
\hline
\end{tabular}

NOTE1: $\mathrm{B}=$ Unstandardized Coefficients Beta, $\mathrm{SE} B=$ Standard Error for Beta, $\beta=$ Standardized Coefficients Beta.

NOTE 2: (a) +ve beta means NO, while -ve beta means YES. (b) -ve beta means more visits. (c) +ve beta means season doesn't make a difference.(d) +ve beta means static water features, while -ve beta means dynamic water features.(e) -ve beta means lot of flowers 
Figure (3) Multiple Regression Models and Normal Distribution of Residuals

\section{A. Sense of Identity}

$\begin{aligned} \text { Community Pride }= & 4.110+(0.650) \text { Outside open space visits }-(0.280) \text { Frequency of visits } \\ & \text { to communal open space }\end{aligned}$

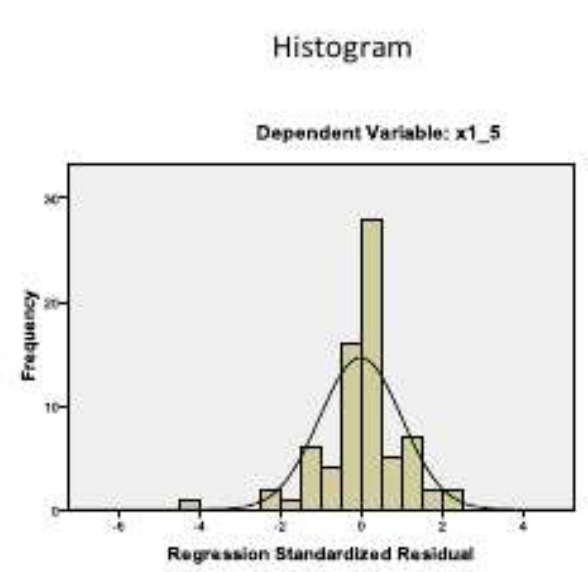

Nort Normal P.P plots of regression standardized residual

B. Sense of Community

Meeting neighbours $=0$

Accompanying children $=0.840+(0.439)$ Children play ground $+(0.298)$ A shared space reachable at walking distance less than 5 minutes
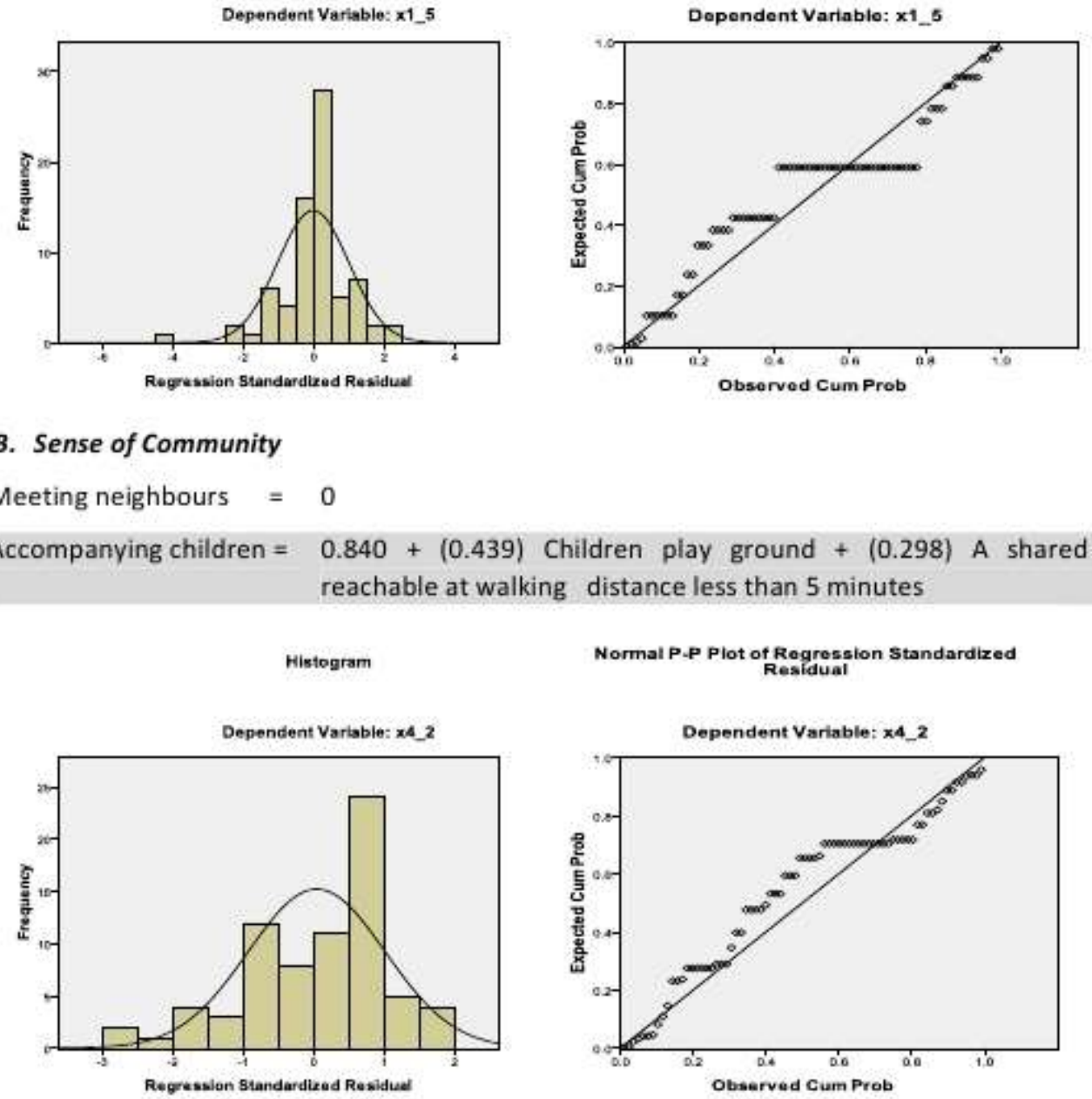

Recreation time with family $=2.178+(0.441)$ Children play ground $+(0.190)$ Preferred season for visiting shared open space $-(0.208)$ Snack bar
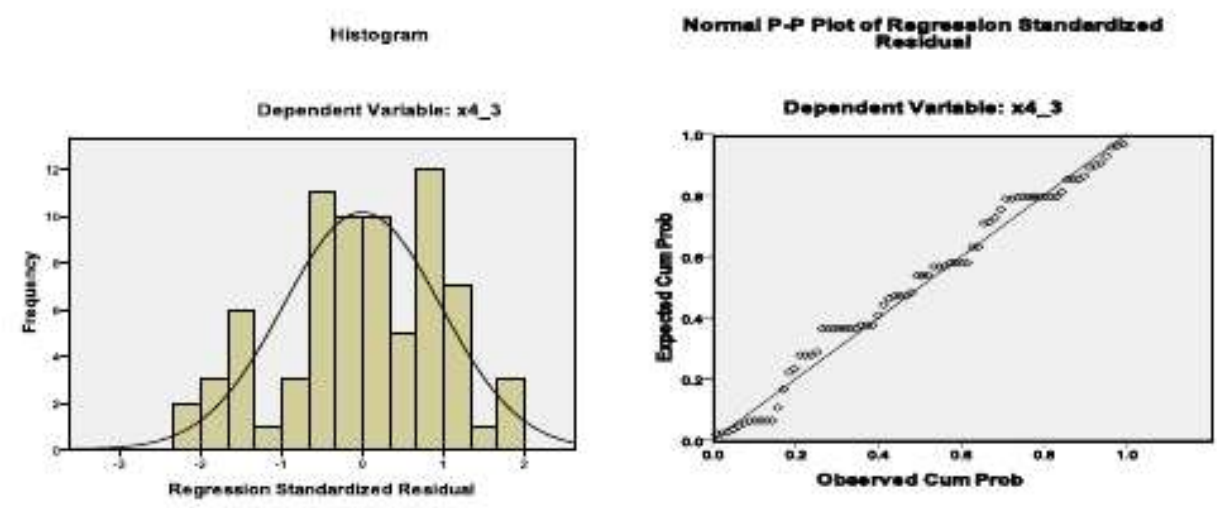

continued 


\section{Sense of Wellbeing}

Doing some sports $=4.712-(0.346)$ Frequency of visits to shared open space $+(0.221)$ Swimming pool $-(0.462)$ water features

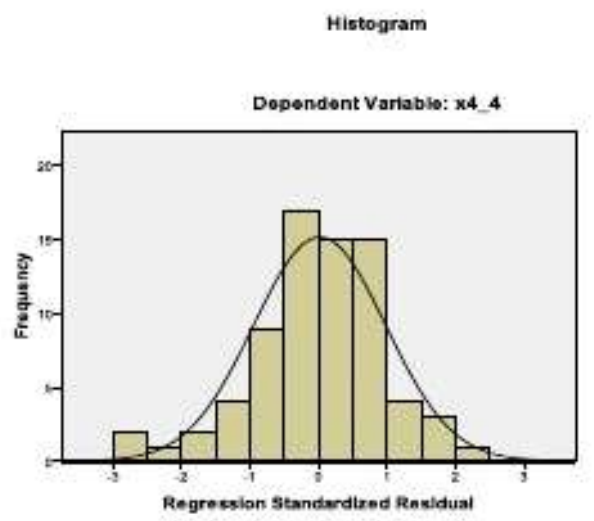

Normal P-P Plot of Regression Standardized Residual

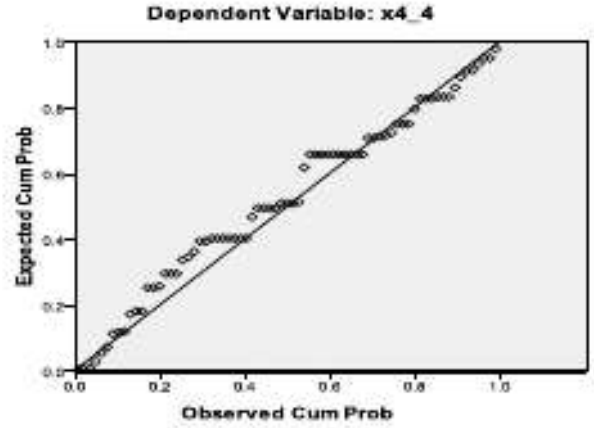

Walking $=4.019+(0.157)$ A shared space reachable at walking distance more than 10 minutes

Hiatogram

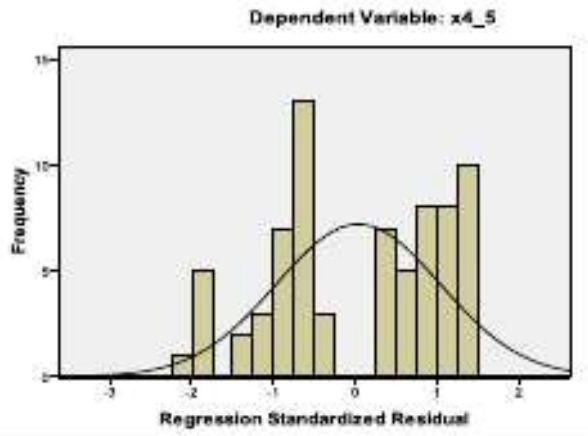

Relaxation \& Enjoying the view = Normal P-P Plot of Regression standardized
Residual

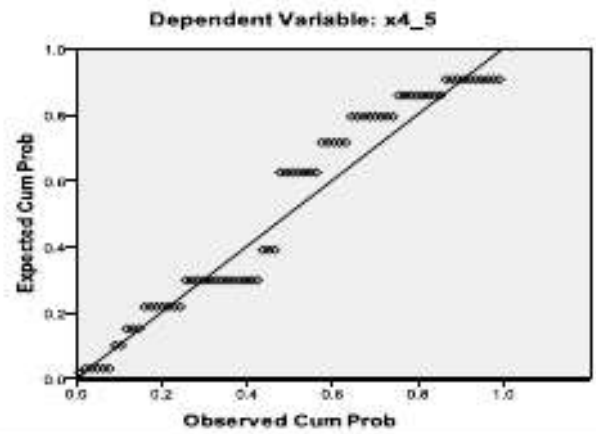

$5.757-(0.502)$ Outside open space visits - $(0.394)$ Flowers
Histogram

Dependent Variable: : xA_ 6

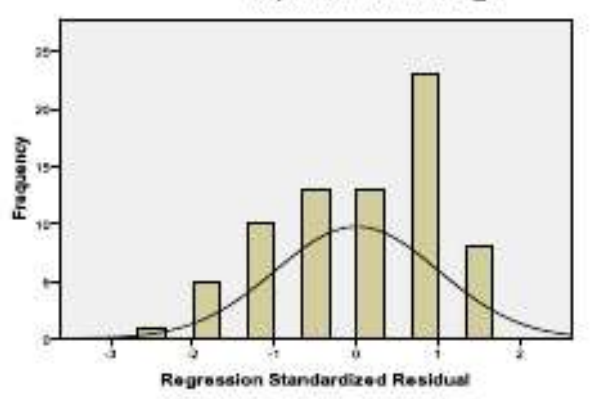
Normal P-p Plot of Regression Standardized
Residual

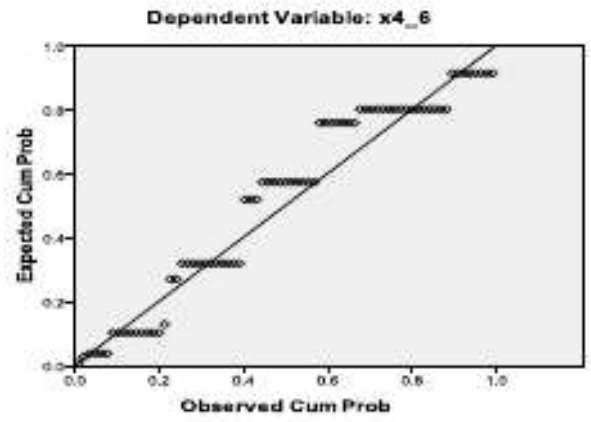

\section{A. Sense of identity}

Based on the ANOVA results $(F(2,65)=12.636, p<0.001)$, there was an overall relationship between the dependent variable 'Sense of identity' [x1_5] and two independent variables: 'Outside open space visits' [E_3]; and 'Frequency of visits to communal open space' $\left[E_{-} 5\right]$. 


\section{B. Sense of community}

- Meeting my neighbours: There is no significance relationship between the dependent variable 'Meeting my neighbours' [x4_1] and any of the independent variables.

- Accompanying children: Based on the ANOVA results $(F(2,65)=13.060, p<0.001)$, there was an overall relationship between the dependent variable 'Accompanying children' [x4_2] and two independent variables: 'Children play ground' [x3_1]; and 'A communal space reachable at walking distance less than 5 minutes' [ x2_4].

- Recreation time with family: Based on the ANOVA results $(F(3,64)=7.484$, $p<0.001)$, there was an overall relationship between the dependent variable 'Recreation time with family' [x4_3] and three independent variables: 'Children play ground' [x3_1]; 'Preferred season for visiting shared open space' $\left[E_{-} 6\right]$; and 'Snack bar' [x3_4].

\section{Sense of well-being}

- Doing some sports: Based on the ANOVA results $(F(3,63)=7.333, p<0.001)$, there was an overall relationship between the dependent variable 'Doing some sports' [x4_4] and three independent variables: 'Frequency of visits to communal open space' [ E_5]; 'Swimming pool' [x3_5] ; and 'Water features' [x5_7].

- Walking: Based on the ANOVA results $(F(1,66)=7.433, p<0.01)$, there was an overall relationship between the dependent variable 'Walking' [ $\mathrm{x}_{-}$5] and one independent variable: 'A communal space reachable at walking distance more than 10 minutes' [x2_6].

- Relaxation \& Enjoying the view: Based on the ANOVA results $(F(2,65)=5.286$, $p<0.01$ ), there was an overall relationship between the dependent variable 'Relaxation \& Enjoying the view' [x4_6] and two independent variables: 'Outside Open Space Visits' [E_3]; and 'Flowers' [x5_4].

\section{DISCUSSION}

The results demonstrate that sense of identity is predicted by fewer visits to outside outdoor spaces and more visits to communal spaces. In this perspective, it could be said that communal spaces contribute so significantly to develop a sense of belonging and pride which is vital in gated residential developments.

Sense of community with neighbours is not predicted by any variables, while sense of community with family is very much predicted by a high preference for children play ground. This result indicates that the space level in the sociability structure depend on people with whom one would wish to engage (family or neighbours). The 
relationships between neighbours in the shared open spaces rely on occasional and superficial encounters. 'Meeting my neighbours' was not very much preferred; it was the seventeenth preference from a total of twenty-three preferences according to its weight value determined by respondents' scores. Site visits and observation of sociability patterns confirm this supposition.

As for sense of well being, 'Doing some sports' is very much predicted by more visits to communal spaces, a preference for swimming pools, and a high preference for dynamic water features (waterfalls and fountains). 'Walking' is predicted by a high preference for a communal space reachable at walking distance more than 10 minutes. Also, 'Relaxation \& enjoying the view' is predicted by a preference for a large amount of flowers.

\section{CONCLUSIONS AND RECOMMENDATIONS}

In order to attract affluent homebuyers, developers compete with each other by providing their gated developments with attractive shared open spaces and recreational facilities (package of collective goods). In this marketplace, consumers/residents 'vote with their feet' sorting themselves into places whose bundles of amenities are desirable and choose those developments that can match their requirements better than others. In this sense, a consideration of what the users might need from a built environment must often be well thought-out.

Accordingly, the current research begins to establish the essential landscape baseline information en route for establishing a generic standard for communal space facilities based on residents' preferences, expectations and usage patterns. Simple analysis of trends shows that the most commonly reported advantages of living in (GRDs) were 'quiet space to live in' and 'privacy', while on the contrary 'sense of community' and 'price \& schedule of payment' were reported as the fewer benefits. Residents very highly preferred a project with gate, a large sized shared space reachable at walking distance less than 5 minutes. Sitting areas, shaded places and children's play ground were very much approved. Walking and enjoying the view were the preferred activities, but meeting neighbours was not very much preferred.

The research findings provide considerable evidence that communal spaces could enhance the quality of urban life for residents' of (GRDs) by establishing a sense of place and community pride. Moreover, a proper management structure and wellmaintained shared open spaces with vegetation add to the physical and psychological health of residents.

Concerning community life inserted in concrete local marketing context, many inhabitants of gated developments do not specifically choose a community life. An individualized lifestyle emerges contributing to a lenient attitude towards social activities among neighbours. Therefore, it is important to reconsider the idea of community life as a marketing tool. 


\section{Acknowledgements}

Special thanks are given to the architect Hala Kamel for her strong support while distributing and collecting the questionnaire, and thanks to the anonymous reviewer.

\section{References}

Bee, A. R. (2000a, 13 Dec 2003). Outdoor Places in Residential Areas - Design approach for the external environment. Retrieved June 7, 2009, from http://www.thesteelvalleyproject.info/green/Places/residential/desig.htm

Bee, A. R. (2000b, 5 Jan 2004). Outdoor Places in Residential Areas - The greenspace concept in housing. Retrieved June 30,2009, from http://www.thesteelvalleyproject.info/green/Places/residential/green.htm

Bill, M. (2001). Problems with Mistaking Community Life for Public Life. Places, 14(2), 48-55.

Clement, J. N. (2004). Social, Restorative and Safe Places: Strategies for Small Urban Open Space Planning and Design. Unpublished MSc, University of Florida.

Francis, M. (2003). Urban Open Space: Designing For User Needs (1st ed.). Washington, D.C: Island Press.

Gehl, J. (2003). Life Between Buildings: Using Public Space (5th ed.). Copenhagen: The Danish Architectural Press.

Kaplan, R. (1983). The Role of Nature in the Urban Context. In I. Altman \& J. F. Wohlwill (Eds.), Behavior and the natural environment (pp. 127-159). New York: Plenum Press.

Kaplan, R. (2001). The Nature of the View from Home. Environment and Behavior, 33(4), 507-542.

Laois County Council. Open Space Considerations for Residential Developments. Retrieved June, 14, 2009, from http://www.laois.ie/media/Media,3531,en.pdf

Marcus, C. C. (2001, March). The Neighborhood Approach to Building Community: A Different Perspective on Smart Growth. Retrieved June 3, 2008, from http://wiki.artemisiadesign.com/download/attachments/393223/ClareCooperMarcu sarticle.doc

Marcus, C. C. (2003). Shared Outdoor Space and Community Life. Places, 15(2), 32-41.

Marcus, C. C., \& Francis, C. (1997). People Places: Design Guidelines for Urban Open Space (2nd ed.). New York: John Wiley \& Sons.

Sullivan, R. (2006). Shared Open Space: Signs of Community Life in the Danish Suburban Landscape. Retrieved June 5, 2009, from http://www.sparkssullivan.com/Fulbright\%20Final.pdf

Talen, E. (2003). A Matter of Priorities: New Urbanism and Community Life. Places, 15(3), 7780.

Thompson, S. (2008). Design for Open Space. Retrieved June 25, 2009, from http://yourdevelopment.org/factsheet/view/id/72/

Tress, B., \& Tress, G. (2001). Capitalising on Multiplicity: A Transdisciplinary Systems Approach to Landscape Research. Landscape and Urban Planning, 57(3-4), 143-157.

Xiaoyu, L., Jian, G., Fei, C., \& Hokao, K. (2007). Residential Environment Evaluation Model and Residential Preferences of the Changjiang Delta Region of China. Journal of Asian Architecture and Building Engineering JAABE, 6(2), 299-306. 